\title{
Potential for Environmental Services Based on the Estimation of Reserved Carbon in the Mangunharjo Mangrove Ecosystem
}

\author{
Hadiyanto Hadiyanto ${ }^{1,4 *}$, M. Arief Rahman Halim ${ }^{1}$, Fuad Muhammad $^{1,2}$, \\ Tri Retnaningsih Soeprobowati ${ }^{1,2}$, Sularto Sularto ${ }^{1,3}$ \\ ${ }^{1}$ School of Postgraduate Studies, Diponegoro University, Indonesia \\ ${ }^{2}$ Biology Department, Faculty of Science and Mathematic, Diponegoro University, Indonesia \\ ${ }^{3}$ Faculty of Law, Diponegoro University, Indonesia \\ ${ }^{4}$ Center of Biomass and Renewable Energy (CBIORE), Diponegoro University, Indonesia
}

Received: 22 April 2020

Accepted: 13 August 2020

\begin{abstract}
The Mangunharjo mangrove ecosystem is one of the areas affected by land degradation because of the creation of ponds. This research evaluated the mangrove potential capacity for carbon storage, particularly in absorbing carbon dioxide $\left(\mathrm{CO}_{2}\right)$ from the environment. The estimation used allometric equations that employ tree type and diameter at breast height. The carbon content in sediment was also evaluated using the ignition method. Results showed that the estimated value of standing carbon stock in the Mangunharjo mangrove ecosystem is 152.85 ton ha ${ }^{-1}$. The highest value (i.e., 68.1 ton ha ${ }^{-1}$ ) is observed in the area near the river, which is dominated by the Avicennia marina species with a density of 733 ind ha ${ }^{-1}$. The lowest value (i.e., 34.69 ton ha $^{-1}$ ) is observed in the area near the residential

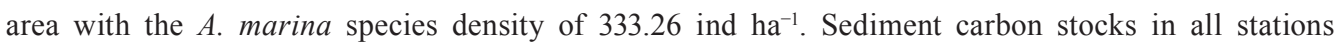
amounted to 236.07 ton $\mathrm{ha}^{-1}$. The amount of carbon in sediment is influenced by the sediment type, vegetation type, and sediment age. The total carbon stock in the Mangunharjo mangrove ecosystem is 388.92 ton $\mathrm{ha}^{-1}$, which can be categorized as high potential for environmental services, that is, to absorb $\mathrm{CO}_{2}$.
\end{abstract}

Keywords: environmental services, mangrove, biomass, carbon

\section{Introduction}

Mangrove ecosystems have an important role in terms of ecological and socioeconomic aspects. Mangrove ecosystems lie along the coast and are

*e-mail: hadiyanto@live.undip.ac.id affected by tides [1]. Mangroves can be considered an ecosystem if a reciprocal relationship exists between fauna and flora within the environment [2]. The physical function of mangroves is to protect the coastline from abrasion caused by waves and increasing land accretion caused by sedimentation processes and serve as carbon sinks that absorb and store the atmosphere's carbon [3]. According to Overbeek [4], mangrove and seagrass ecosystems can store carbon from the atmosphere 
in the form of sediments and soil. According to Murdiyarso et al. [5], mangrove ecosystems can store more carbon than the ecosystem in general. Moreover, mangrove ecosystems play an important role in global climate change mitigation efforts (global warming) [6]. Mangrove ecosystems in coastal areas effectively reduce the concentration of carbon dioxide $\left(\mathrm{CO}_{2}\right)$ in the atmosphere because mangroves can absorb $\mathrm{CO}_{2}$ through photosynthesis by diffusion through stomata and store carbon in the form of biomass, which is distributed to the leaves, stems, wood, and sediments. According to data from the International Panel on Climate Change 2003, in the late 1980s, world carbon emissions amounted to $82-152$ Gton $\mathrm{C}$; this number continued to increase until the 20th century as a result of burning fossil energy, land conversion, and burning forest. The United Nations Framework Convention on Climate Change stated that reducing emissions from deforestation and forest degradation (REDD+) is the best way to mitigate climate change. On the basis of this statement, the Indonesian government, through the National Action Plan for Reducing Greenhouse Gas Emissions outlined in Presidential Regulation No. $61 / 2011$, aims to reduce greenhouse gas emissions by $26 \%$ through its efforts and by $41 \%$ with international assistance by 2020 . The forest and peatland sectors are some of the sectors that have been highlighted in the government's plan to reduce greenhouse gas emissions. Activities, such as the prevention of deforestation and forest degradation, conservation, and reforestation, are some of the ways to improve the function of forests in absorbing $\mathrm{CO}_{2}$.

Mangunharjo Village, which has a mangrove ecosystem, is located on the northern coast of Semarang City. The area of the mangrove ecosystem changes from year to year. At the beginning of 1990, the Mangunharjo mangrove ecosystem was a natural forest. The area of the Mangunharjo mangrove ecosystem is \pm 226.07 ha. Over time, the needs of the local community increased, which resulted in illegal logging and land conversion into shrimp farming ponds. In 1995, abrasion resulted in the loss of mangrove area by $50 \%$ from its initial area. After the event, the community became aware of the importance of the function of mangroves. Wild mangrove planting began in 1998. The community continued cultivating mangroves in 2002 by planting Avicennia and Rhizophora species. The activity is ongoing, and the current mangrove area is \pm 46.19 ha. These events show that the conversion of mangrove land will considerably affect the sequestration and degradation of carbon, which will be stored through the decomposition process in the atmosphere. The function of mangroves will change from being an absorber and a reservoir of $\mathrm{CO}_{2}$ to being a contributor to $\mathrm{CO}_{2}$ emissions, which will significantly influence climate change. Carbon storage potential is observed not only in the stem but also in mangrove sediments.

According to Robinson [7], mangrove ecosystems store carbon four times more than tropical forest ecosystems. The estimated amount of carbon contained in the mangrove ecosystem can be used as a basic reference in assessing the benefits of mangrove and its potential for environmental services. This research on the estimation of mangrove ecosystem carbon stocks highlights the importance of mangrove monitoring and rehabilitation as an effort to mitigate climate change (global warming).

\section{Experimental}

This research was conducted from November 2018 to December 2018 in the Mangunharjo mangrove ecosystem in Mangunharjo Village, Semarang City. The observation area is divided into three zones. In each zone, one measurement transect in the form of a $10 \mathrm{~m} \times 30 \mathrm{~m}$ plot was made for purposive sampling. This study focused only on the tree category of mangrove vegetation because the carbon absorption of the stake and pole categories is low. The vegetation analysis method was used to determine the community structure in the Mangunharjo mangrove ecosystem. Vegetation analysis calculates the relative density (KR), relative frequency (FR), and relative dominance (DR), which subsequently form the importance value index (INP) [8]. Species diversity can be used to express community structure. Species diversity can also be used to measure community stability, that is, the capability of a community to keep itself stable even though there are disruptions to its components. Species diversity is calculated using the Shannon-Wiener diversity index. The value of the evenness index $(E)$ can describe the stability of a community and ranges from 0 to 1 . The smaller the value of $E$ or the closer the value of $E$ to 0 , the more uneven the distribution of organisms in the community (i.e., dominated by certain species). Conversely, the larger the value of $E$ or the closer the value of $E$ to 1, the more even the distribution of organisms in the community.

Measurement of tree canopy cover is done by using the hemispherical photography method, which utilizes photos and focuses attention on the $180^{\circ}$ viewing angle at the point of taking photos. According to Reinert et al [9], each $10 \mathrm{~m} \times 10 \mathrm{~m}$ plot is divided into four smaller plots measuring $5 \mathrm{~m} \times 5 \mathrm{~m}$. The point of taking photos at the center of a small plot, that is, between one tree and another tree, is to avoid shooting right on the side or near one tree. The camera is aligned with the height of the chest and positioned perpendicular to the sky. In this study, the researchers used the application CanopyApp for android mobile.

The sampling of tree biomass through the nondestructive method involves recording the tree type and measuring the diameter at breast height. According to Komiyama et al. [10] and Lugina et al. [11], the retrieval of tree biomass data is done by measuring the diameter $(>10 \mathrm{~cm})$ of tree trunks at breast height (1.3 $\mathrm{m}$ tree height) and inputting the data into existing 
allometric equations on the basis of the tree type. Then, the biomass value of mangrove trees is multiplied by 0.47 to obtain the carbon value.

Sediment sampling was conducted at a depth of $20 \mathrm{~cm}$ from the surface of each plot at three stations. The samples taken were weighed, placed in aluminum foil, marked according to the plot point, taken to the laboratory, and analyzed using the ignition method. The data analyzed included the depth of sediment samples, soil density, percentage of organic matter lost during combustion, percentage of organic carbon, soil carbon density, and carbon stock in ton $\mathrm{ha}^{-1}$ [12].

\section{Results and Discussion}

From the results of the analysis of vegetation in the Mangunharjo mangrove ecosystem, seven species were identified, namely, Rhizophora mucronata, Rhizophora stylosa, Rhizophora apiculata, Avicennia marina, Avicennia officinalis, Bruguiera gymnorrhiza, and Xylocarpus moluccensis. The dominant species in all stations are A. marina and $R$. mucronata. The mangrove species found in each station are shown in Table 1 . The values of FR, KR, and DR are highest in Station 3, with A. marina having the highest value (i.e., $66.67 \%$ for FR, $80 \%$ for KR, and $83.67 \%$ for DR).

The diversity and evenness values of all research stations are also shown in Table 1. All stations have low diversity, and the Mangunharjo mangrove ecosystem is observed to be unstable. Diversity is an indicator of the stability of mangrove growth under different environmental conditions. High stability indicates a high level of complexity, which can be attributed to high interaction, leading to high capability to deal with disruptions to its components. If the diversity index is stable, then each species will have an organized, efficient, and productive life cycle. The degree of dominance can be attributed to the fact that the local community in the Mangunharjo region prefers to plant mangroves from the $R$. mucronata and A. marina species because these two species can adapt to the environment and have a rapid and easy breeding process.

The Santren River Institute and the Sustainable Mangrove Group are environmentally conscious groups that have exerted considerable efforts to rehabilitate mangroves in the coastal area of Mangunharjo. In 2011-2012, the Santren River Institute planted 50,000 mangroves from the $R$. mucronata, $R$. apiculata, A. marina, and B. gymnorrhiza species. The Sustainable Mangrove Group established nurseries and planted mangroves from the Rhizophora and A. marina species. According to Agus et al. [13], the diversity value of a community is dependent on the number of species and the number of individuals found in the community. The diversity of a community will be high if it is composed of many species and there is no dominant species.

Table 1. Density, Basal Area, and Importance Value Index (INP) of Mangrove Species.

\begin{tabular}{|c|c|c|c|c|c|c|c|}
\hline \multirow{2}{*}{ Location/Species } & Density & Basal Area & \multirow{2}{*}{ Frequency } & KR & DR & FR & INP \\
\hline & (ind $\mathrm{ha}^{-1}$ ) & $\left(\mathbf{m}^{2} \mathbf{h a}^{-1}\right)$ & & $(\%)$ & $(\%)$ & $(\%)$ & $(\%)$ \\
\hline \multicolumn{8}{|c|}{ Station 1} \\
\hline Rhizophora mucronata & 400 & 0.44 & 1 & 66.67 & 69.26 & 43.1 & 179.03 \\
\hline Rhizophora stylosa & 100 & 0.027 & 0.33 & 16.67 & 17.31 & 14.22 & 48.2 \\
\hline Rhizophora apiculata & 66.66 & 0.012 & 0.66 & 11.11 & 7.76 & 28.45 & 47.32 \\
\hline Bruguiera gymnorrhiza & 33.33 & 0.003 & 0.66 & 5.55 & 5.67 & 14.22 & 25.44 \\
\hline Total & 599.99 & 0.48 & 2.32 & 100 & 100 & 100 & 300 \\
\hline \multicolumn{8}{|c|}{ Station 2} \\
\hline Avicennia marina & 566.66 & 0.59 & 1 & 77.27 & 80.05 & 50.25 & 207.57 \\
\hline Avicennia officinalis & 133.33 & 0.033 & 0.66 & 18.18 & 15.94 & 33.17 & 67.29 \\
\hline Xylocarpus moluccensis & 33.33 & 0.002 & 0.33 & 4.55 & 4.01 & 16.58 & 25.14 \\
\hline Total & 733.32 & 0.63 & 1.99 & 100 & 100 & 100 & 300 \\
\hline \multicolumn{8}{|c|}{ Station 3} \\
\hline Avicennia marina & 266.6 & 0.64 & 0.66 & 80 & 83.67 & 66.67 & 230.34 \\
\hline Rhizophora mucronata & 66.66 & 0.04 & 0.33 & 20 & 16.33 & 33.33 & 69.66 \\
\hline Total & 333.26 & 0.68 & 0.99 & 100 & 100 & 100 & 300 \\
\hline \multicolumn{2}{|c|}{ Diversity Index $\left(H^{\prime}\right)$} & 0.7 & \multicolumn{5}{|c|}{ Low } \\
\hline \multicolumn{2}{|c|}{ Equity Index ( $\left.E^{\prime}\right)$} & 0.67 & \multicolumn{5}{|c|}{ Unstable } \\
\hline
\end{tabular}


Table 2. Type and Composition of Sediments in the Mangunharjo Mangrove Ecosystem.

\begin{tabular}{|c|c|c|c|}
\hline \multirow{2}{*}{ Station } & \multicolumn{3}{|c|}{ Category } \\
\cline { 2 - 4 } & Sand (\%) & Silt (\%) & Clay (\%) \\
\hline 1 & 94.76 & 5.24 & 0 \\
\hline 2 & 6.64 & 66.36 & 27 \\
\hline 3 & 14.12 & 73.88 & 12 \\
\hline
\end{tabular}

The INP is an index calculated on the basis of the degree of dominance in a plant community. The INP of mangrove vegetation can be obtained from the sum of the FR, KR, and DR expressed in percent [13]. The results of the calculations made for the three observation stations show the differences in the value of the INP for each mangrove species, where $A$. marina has the highest INP (i.e., 207.57\%) and $X$. moluccensis has the lowest INP (i.e., 25.14\%) in Station 2. The INP shows the range of indices that describe the community structure and distribution pattern of mangrove [22]. The differences in the INP of mangrove vegetation can be attributed to competition between species to obtain nutrients and sunlight in the study area. Apart from nutrients and sunlight, another factor that causes differences in the density of mangrove vegetation is sediment type. Table 2 shows that the dominant sediment type in Stations 2 and 3 is silt at $66.36 \%$ and $73.88 \%$, respectively, and the dominant sediment type in Station 1 is sand at $94.76 \%$. Meanwhile, clay is not dominant in all research stations because Station 1 is located close to the sea where the dominant sediment type is sand and Stations 2 and 3 are located far from the sea where the type of soil/substrate is affected by soil erosion from upstream areas [14]. Sand-dominated substrate is generally found in A. marina and R. mucronata species. Substrates that are good for mangrove growth are sandy silt types because mangrove roots can penetrate nutrient-rich substrate layers [15]. Environmental factors can also affect mangrove growth. Tides are a factor that also affects the availability of brackish water, which affects the salinity of the mangrove habitat. Environmental factors in all stations in the Mangunharjo mangrove ecosystem were observed, and vegetation taken in the morning between 8:00 and 9:00 under low tide conditions was analyzed using three replicates for each station. The environmental factors observed in all stations are shown in Table 3.
Table 4 shows that the biomass and carbon stocks in stands in each research plot have different values. The value of carbon reserves always increases with the increase in biomass and density. Density is also observed to affect the values of biomass and carbon reserves [16]. Station 2 has a higher density (i.e., 733.32 ind $\mathrm{ha}^{-1}$ ) and larger carbon reserve (i.e., 68.10 ton $\mathrm{ha}^{-1}$ ) than Stations 1 and 3. The density of an ecosystem indicates the number of individual trees. The more the number of individual trees, the more carbon is absorbed through photosynthesis; thus, the carbon content is high [17]. Correlation analysis also shows a strong relationship between density and biomass, the value of which is 0.994 . The tight condition of mangroves ensured minimal damage in the area. Mangrove areas close to the coast have a lower density than mangrove areas at the center (i.e., 600 ind $\mathrm{ha}^{-1}$ ). This finding can be attributed to the fact that mangroves located in areas near the coast are still relatively young at the age of planting, many of which are suspected of failing to survive because of the waves. Meanwhile, mangrove areas near settlements have the lowest density (i.e., 332.26 ind $\mathrm{ha}^{-1}$ ). This condition is caused by the presence of goats that are deliberately released to forage in the mangrove ecosystem. The goats will eat the mangrove trees that they can reach, causing damage to the mangrove trees. The transfer of land functions and the construction of nonpermanent buildings further aggravate the conditions in Station 3. The research conducted by Kauffman et al. [18] on the carbon content in Perancak Bali mangrove forest showed that Station 1 had the highest carbon content (i.e., 39.97 ton $\mathrm{ha}^{-1}$ ), which was supported by the high density and the dominance of the Rhizophora species. Kauffman et al. [18] further stated that the Rhizophora species had higher biomass and carbon content than the other species. This finding is different from the results of the Mangunharjo mangrove ecosystem. Mangrove forests in Jembrana Bali are natural, whereas those in Mangunharjo are the result of planting after the area was damaged by abrasion.

Canopy cover is influenced by the age, diameter, and density of vegetation. The greater the canopy cover of vegetation is, the greater the biomass, diameter, and density. According to the KepMen LH No. 201 Tahun 2004, the Mangunharjo mangrove ecosystem has good mangrove canopy cover criteria. Correlation analysis also shows a strong relationship between canopy cover and tree biomass content, the value of which is 0.837 . That is, the greater the canopy cover

Table 3. Measurement of Environmental Parameters in the Mangunharjo Mangrove Ecosystem.

\begin{tabular}{|c|c|c|c|c|c|}
\hline Station & Salinity $(\mathrm{ppm})$ & Temperature $\left({ }^{\circ} \mathrm{C}\right)$ & Humidity $(\%)$ & DO $(\mathrm{ppm})$ & $\mathrm{pH}$ of Water \\
\hline I & 32.69 & 29 & 81.33 & 3.53 & 6.6 \\
\hline II & 25.50 & 28 & 80.97 & 4.60 & 6.7 \\
\hline III & 25.12 & 28 & 80 & 4.8 & 6.7 \\
\hline
\end{tabular}


Table 4. Density, Canopy Cover, Biomass, and Carbon Content in the Mangunharjo Mangrove Ecosystem.

\begin{tabular}{|c|c|c|c|c|c|c|c|}
\hline Station & Mangrove Species & $\mathrm{Ni}$ & $\begin{array}{l}\text { Density } \\
\text { (ind ha' }{ }^{-1} \text { ) }\end{array}$ & $\begin{array}{c}\text { Canopy Cover } \\
(\%)\end{array}$ & $\begin{array}{c}\text { Biomass } \\
\left(\text { ton ha }^{-1}\right)\end{array}$ & $\begin{array}{c}\text { Carbon } \\
\left(\text { ton ha }{ }^{-1}\right)\end{array}$ & Total C Vegetation \\
\hline \multirow{5}{*}{1} & Rhizophora mucronata & 12 & 400 & \multirow{5}{*}{73.08} & 83.62 & 39.30 & \multirow{12}{*}{152.89} \\
\hline & Rhizophora stylosa & 3 & 100 & & 16.98 & 7.98 & \\
\hline & Rhizophora apiculata & 2 & 66.66 & & 4.04 & 1.89 & \\
\hline & Bruguiera gymnorrhiza & 1 & 33.33 & & 1.86 & 0.87 & \\
\hline & Total & 18 & 599.99 & & 106.51 & 50.06 & \\
\hline \multirow{4}{*}{2} & Avicennia marina & 17 & 566.66 & \multirow{4}{*}{81.13} & 125.17 & 58.83 & \\
\hline & Avicennia officinalis & 4 & 133.33 & & 14.98 & 7.04 & \\
\hline & Xylocarpus moluccensis & 1 & 33.33 & & 4.73 & 2.22 & \\
\hline & Total & 22 & 733.32 & & 144.9 & 68.10 & \\
\hline \multirow{3}{*}{3} & Avicennia marina & 8 & 266.66 & \multirow{3}{*}{69.56} & 59.3 & 27.87 & \\
\hline & Rhizophora mucronata & 2 & 66.66 & & 14.5 & 6.81 & \\
\hline & Total & 10 & 333.26 & & 73.81 & 34.69 & \\
\hline
\end{tabular}

is, the greater the biomass content. Canopy cover has an important role in the environment of the mangrove ecosystem. Areas covered by a canopy are protected from dryness because the soil is not directly exposed to sunlight, leading to low temperature and high humidity. The soil in the mangrove ecosystem is prone to washing/eroding because of the low bulk density of the soil. The canopy is the part of the plant that holds rainwater and protects what is beneath it, including sediments. This condition can reduce the loss of organic matter due to land washing because the kinetic energy of rainwater decreases [15]. Table 5 shows that Station 2 has the largest total carbon deposit in sediments, amounting to 91.3 ton $\mathrm{ha}^{-1}$. Station 3 has the second largest total carbon deposit in sediments, amounting to 76.22 ton $\mathrm{ha}^{-1}$, and Station 3 has the smallest total carbon deposit in sediments, amounting to 68.56 ton $\mathrm{ha}^{-1}$. The total carbon stock in sediments of the Mangunharjo mangrove ecosystem was 236.07 ton $\mathrm{ha}^{-1}$.

The results showed that the three research stations contained different carbon reserves in mangrove sediments at each station and each plot. This finding has several supporting factors, namely, sediment type, environmental parameters, station location, density, and mangrove species. The results of the laboratory analysis showed that the bulk density of all sediment samples ranges from 0.057 ton $\mathrm{m}^{-3}$ to 0.071 ton $\mathrm{m}^{-3}$. The range of the bulk density in the Mangunharjo mangrove ecosystem is lower than that in Sengon agroforestry land in Malang City (1.35 ton $\left.\mathrm{m}^{-3}\right)$ [19] and East Kalimantan Kutai National Park (1.28 ton $\mathrm{m}^{-3}$ ) [20]. The average bulk density of the mangrove ecosystem is between 0.05 ton $\mathrm{m}^{-3}$ and 0.112 ton $\mathrm{m}^{-3}$; this value increases with the increase in depth $[21,22]$. The low bulk density in the mangrove ecosystem can be attributed to the dominance of sand. The lower the bulk density is, the higher the level of porosity. Thus, water can easily enter the pore space of soil, which will adequately maintain the water availability for the mangrove ecosystem. Station 2 has a higher total carbon stock in mangrove sediments (i.e., 91.3 ton $\mathrm{ha}^{-1}$ ) than the other stations. Station 2 has sandy silt sediment and is located far from the sea but near the river. Many microorganisms are assumed to be deposited on the substrate, thus affecting the percentage of organic matter, which will affect the calculation of sediment carbon stocks. In Station 2, which is far from the sea, organic matter will be easily precipitated because the condition of the waters is relatively calm and not affected by ocean waves. This finding is supported by Nybakken [23], who stated that particle motion in calm water will affect the sedimentation

Table 5. Bulk Density and Sediment Carbon Reserves.

\begin{tabular}{|c|c|c|c|}
\hline Station & Bulk Density $\left(\mathbf{t ~ m}^{-3}\right)$ & \multicolumn{2}{|c|}{ Carbon Stock (ton ha $\left.{ }^{-1}\right)$} \\
\hline \multirow{3}{*}{1} & 0.0544 & 22.50 & \multirow{3}{*}{68.56} \\
\hline & 0.0552 & 22.49 & \\
\hline & 0.0579 & 23.58 & \\
\hline \multirow{3}{*}{2} & 0.0715 & 30.98 & \multirow{3}{*}{91.3} \\
\hline & 0.0706 & 30.40 & \\
\hline & 0.0693 & 29.92 & \\
\hline \multirow{3}{*}{3} & 0.0611 & 25.71 & \multirow{3}{*}{76.22} \\
\hline & 0.0610 & 25.61 & \\
\hline & 0.0594 & 24.89 & \\
\hline \multicolumn{3}{|c|}{ Total C Sediment (ton $\mathrm{ha}^{-1}$ ) } & 236.07 \\
\hline
\end{tabular}


of organic matter. The density in Station 2 is higher than that in other stations because the A. marina, $A$. officinalis, and $X$. moluccensis species are all present in this station. This environmental condition is supported by the sediment type, that is, sandy silt, which is the habitat favored by the Avicennia species as it can grow optimally because it is far from waves [24] and it has a high content of organic matter and decomposing bacteria capable of decomposing mangrove.

The density, percentage of canopy cover, and carbon content in Station 2 are the highest, followed by those in Station 1, and those in Station 3 are the lowest. The difference depends on the carbon content in sediment. Station 2 has the highest carbon content, followed by Station 3, and Station 1 has the lowest carbon content. This finding can be attributed to the fact that, in Station 1, the dominant sediment type is sand and the bulk density is lower than that in other stations (i.e., 0.05 ton $\mathrm{m}^{-3}$ ). Meanwhile, in Station 3, the dominant sediment type is silt and the bulk density is 0.06 ton $\mathrm{m}^{-3}$. According to Stringer et al. [22], sandy soil has a low bulk density but has more mineral content than organic matter content. The decomposition process on sandy substrate is slower than that on sandy silt substrate because of the diversity of macrozoobenthos [25]. According to Miller et al. [26], macrozoobenthos can be generally found in larger quantities on sandy sludge substrates than on sandy substrates. In addition to differences in soil types, the effect of differences in species living in each station was analyzed. The $A$. marina species has a small leaf structure but a large number of leaves; thus, the amount of litter produced is also large. This statement is supported by Eid et al. [27], who stated that the production and content of organic carbon litter of the A. marina species are more than those of other species. The amount of litter produced reached $111.25 \mathrm{~g} \mathrm{~m}^{-2}$ and the organic carbon value was $51.87 \%$. Station 3 is dominated by the A. marina species and contains a higher sediment carbon stock than
Station 1 because of the high litter productivity and organic carbon content of the A. marina species. Under the environmental conditions, Station 1 has a large quantity of sandy substrates covered by the broad leaves of Rhizophora, but its litter productivity (82 $\mathrm{g} \mathrm{m}^{-2}$ ) and organic carbon content (39\%) are smaller than those of Avicennia species [27]. Sandy silt in Station 3 also plays a role in the litter composting process, causing the carbon content in the litter to be trapped in sediment through the biogeochemical cycle. The difference in carbon content in sediments is also caused by the age of vegetation and sediment. Alongi [28] observed the correlation between the content of organic carbon in sediments and the age of mangrove vegetation. The older the age of vegetation is, the older the age of sediment where vegetation grows and the higher the content of stored organic carbon. Research on the comparison of standing carbon and carbon in sediments conducted by Santos et al. [14] in the southeastern mangrove forests of Mexico showed that the highest carbon content in sediment of 152.76 ton $\mathrm{ha}^{-1}$; meanwhile, the carbon content in the mangrove stands is 92,38 ton $\mathrm{ha}^{-1}$. This finding shows that sediment in mangroves has the potential capacity for carbon storage for a long time [29] because the strong roots of mangrove can bind the sediment substrate, thereby minimizing soil erosion.

The study conducted by Santos et al. [14] showed that the highest carbon content in the Mangunharjo mangrove ecosystem is observed in sediments. The total carbon in sediment (i.e., $60.7 \%$ or 236.07 ton $\mathrm{ha}^{-1}$ ) is higher than the standing carbon (i.e., 39.3\% or 152.85 ton $\mathrm{ha}^{-1}$ ) (Fig. 1). The total amount of carbon stored in the Mangunharjo mangrove ecosystem both in vegetation and sediment is 388.92 ton $\mathrm{ha}^{-1}$. These values indicate that the magnitude of the potential of the Mangunharjo mangrove ecosystem to absorb carbon can be categorized as high [30,31]. Iverson et al. [30] categorized the size of carbon stocks through
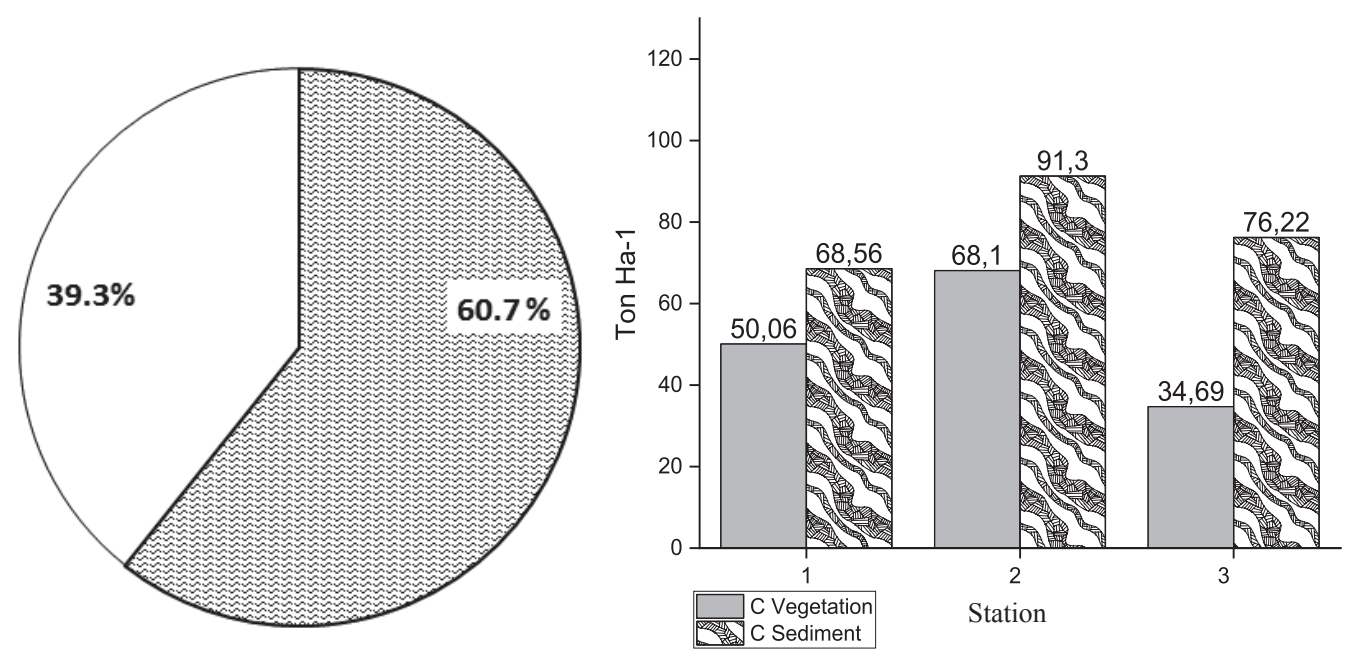

Fig. 1. Comparison of Carbon Reserves in Vegetation and Sediments. 
the GIS approach by grouping the pixel colors from satellite imagery. Pixels that have a value of more than 100 ton $\mathrm{ha}^{-1}$ are categorized as exhibiting high absorption of carbon. By contrast, Kraenzel et al. [31] reported that the distribution of the category of carbon absorption refers to the national REDD+ strategy, which states that the absorption value of forest ecosystems can be categorized as low (i.e., $<35$ ton $\mathrm{C} \mathrm{ha}^{-1}$ ), medium (36-100 ton $\left.\mathrm{C} \mathrm{ha}^{-1}\right)$, and high $\left(>100\right.$ ton $\left.\mathrm{C} \mathrm{ha}^{-1}\right)$.

\section{Conclusions}

The Mangunharjo mangrove ecosystem has a low diversity and an unstable community because it is dominated by the A. marina species. Density affects the value of biomass and carbon in vegetation. Carbon reserves in sediment are influenced by the substrate type, litterfall, and sediment age. The results showed that carbon deposits are more abundant in sediment substrate than in plant bodies.

\section{Acknowledgements}

The authors thank to School of Postgraduate Studies, Universitas Diponegoro for supporting fund to conduct this research in 2019. The authors also thank to Mr. Sururi and Mr. Muharor for their assistance in data collection fields.

\section{Conflict of Interest}

The authors declare no conflict of interest.

\section{References}

1. CHOONG E.T., WIRAKUSUMAH R.S, ACHMADI S.S. Mangrove forest resources in Indonesia. Forest Ecology and Management 31, 45, 1990.

2. FARHAN A.R., LIM S. Integrated coastal zone management towards Indonesia global ocean observing system (INA-GOOS): Review and recommendation. Ocean \& Coastal Management. 53 (8), 421, 2010.

3. BURBRIDGE P.R., KOESOEBIONO, K. Management of mangrove exploitation in Indonesia. Applied Geography. 2 (1), 39, 1982v

4. OVERBEEK W. Blue Carbon and Blue Redd Transforming Coastal Ecosystem, Into Merchandise. Misereor (Jerman) and Swedish Society for Nature Conservation (SSNC), 2014.

5. MURDIYARSO D., DANIEL D., BOONE J.K., SOFYAN K., MELANIE S., MARKKU S.K. Carbon Stocks in Mangrove and Peatland Ecosystems. CIFOR, Bogor Indonesia, 2010.

6. DONATO D.C., KAUFFMAN, J.B., MURDIYARSO, D., KURNIANTO, S., STIDHAM, M., KANNINEN, M. Mangroves Among the Most Carbon-Rich Forests in the Tropics. Nature Geoscience. 4, 293, 2011.
7. ROBINSON S. Sink and Source Awesome Mangroves. WWF., 2013.

8. AGRAWAL A. Forests, governance, and sustainability: common property theory and its contributions. International Journal of the Commons. 1 (1), 111, 2007.

9. REINERT F., DE PINHO C.F., FERREIRA M.A. Diagnosing the level of stress on a mangrove species (Laguncularia racemosa) contaminated with oil: A necessary step for monitoring mangrove ecosystems. Marine Pollution Bulletin. 113 (1-2), 94, 2016.

10. KOMIYAMA A., POUNGPAM S., KARTO S. Common Allometric Equations for estimating the tree weight of mangroves. Journal of Tropical Ecology. Cambridge University Press, 21 (4), 2005.

11. JONSSON M.N., HEDMAN A.M. Carbon stock assessment of mangrove ecosystems in Batticaloa Lagoon, Sri Lanka, with different degrees of human disturbances. Singapore Journal of Tropical Geography 40 (2), 199, 2019.

12. UDDIN J., MOHIUDDIN, A.S.M, HASSAN M. Organic carbon storage in the tropical peat soils and its impact on climate change. American Journal of Climate Change. 8 (1), 329, 2016.

13. AGUS C., PUTRA P.B., FARIDAH, E., WULANDARI D, NAPITUPULU R.R.P. Organic carbon stock and their dynamics in rehabilitation ecosystem areas of post open coal mining at tropical region. Procedia Engineering 159 (1), 45, 2013.

14. SANTOS J.G., JESÚS G. CERÓN., R.M. CERÓN., J. ANGEL., A. HERNÁNDEZ, D. JUNCO., REYNA. Allometric equations to estimate carbon pool in soil and above-ground biomass in mangrove forests in southeast Mexico. Journal of Forestry Research., 25, 125, 2013.

15. BROWN S., SATHAYE J., CANNELL M., KAUPPI P.E. Mitigation of carbon emissions to the atmosphere by forest management. The Commonwealth Forestry Review, 75 (1), 80, 1996.

16. RACHMAWATI D., ISDRAJAD., HILMI E. Potensi Estimasi Karbon Tersimpan Pada Vegetasi Mangrove di Wilayah Pesisir Muara Sungai Gembong Bekasi. OmniAkuatika 13 (19), 85, 2014.

17. KUSMANA C., TAKEDA S., WATANABE H. Litter production of a mangrove forest in East Sumatera, Indonesia. Indonesian Journal of Tropical Agriculture. 8 (3), 52, 1997.

18. KAUFFMAN J.B., COLE T.G. Micronesian mangrove forest structure and tree responses to a severe typhoon. Wetlands, 30 (6), 1077, 2010.

19. VICIEDO D.O., HERNÁNDEZ A., RODRÍGUEZ M., LIZCANO R., CALERO A., PEÑA K. Effects of land-use change on Nitisols properties in a tropical climate. Revista Facultad Nacional de Agronomía Medellín, 71 (3), 8601, 2018.

20. EDWARDS R.B., NAYLOR R.L., HIGGINS M.M., FALCON W.P. Causes of Indonesia's forest fires. World Development. 127, 104717, 2020.

21. MYONG Y., BAIPENG P., GUANGCHENG C., YAN C. Processes of organic carbon in mangrove ecosystems. Acta Ecologica Sinica. 31 (3), 169, 2011.

22. STRINGER C., TRETIN C., ZARNOCH S. Soil Properties of mangrove in contrasting geomorphic settings within the Zambezi River Delta Mozambique. Wetlands Ecology and Management. 24, 139, 2016.

23. CASTILLA J.C. Roles of experimental marine ecology in coastal management and conservation. Journal of Experimental Marine Biology and Ecology. 250 (1-2), 3, 2000. 
24. TOMLINSON P.B. The Botany of Mangroves. Cambridge University Press. New York, 1994.

25. CHRISTENSEN B. Biomass and primary production of Rhizophora apiculata Bl. in a mangrove in southern Thailand. Aquatic Botany. 4, 43, 1978.

26. MILLER D., SEMMENS K. Waste Management in Aquaculture. Aquaculture Information Series. 1 (2), 1, 2002.

27. EID E.M., KHEDHER K.M., AYED H., ARSHAD M., MOATAMED A., MOULDI A. Evaluation of carbon stock in the sediment of two mangrove species, Avicenna marina and Rhizopora mucronata, growing in the Farasan islands, Saudi Arabia. Oceanol. 62, 200, 2020.

28. ALONGI D.M. The impact of climate change on mangrove forests. Current Climate Change Reports. 1, 30, 2009.
29. ABINO, AZYLEAH C., JOSE A., CASTILlO A., LEE Y.J. Assessment of species diversity, biomass and carbon sequestration potential of a natural mangrove stand in Samar the Philippines. Forest Science and Technology. 10 (1), 2, 2014.

30. IVERSON L.R., BROWN S., GRAINGER A., PRASAD A., LIU D. Carbon sequestration in tropical Asia: an assessment of technically suitable forest lands using geographic information system analysis. Climate Research. 3, 23, 1993.

31. KRAENZEL M., CASTILlO A., MOORE T. \& POTVIN C. Carbon storage of harvest-age teak (Tectona grandis) plantations, Panama. Forest Ecology and Management. 173, 213, 2003. 